\title{
Association of morning fasting blood glucose variability with insulin antibodies and clinical factors in type 1 diabetes
}

\author{
Chihiro Yoneda, Kanako Tashima-Horie, Sayaka Fukushima, Satoko Saito, Sayoko Tanaka, \\ Takenori Haruki, Jun Ogino, Yoshifumi Suzuki and Naotake Hashimoto
}

Department of Diabetes, Endocrine and Metabolic Diseases, Tokyo Women's Medical University, Yachiyo Medical Center, Yachiyo 276-8524, Japan

\begin{abstract}
The fasting blood glucose concentration in type 1 diabetes may vary without being much affected by diet and exercise. This study aimed to identify association of morning fasting blood glucose concentration variability with insulin antibodies and clinical factors. The subjects in this study were 54 patients with type 1 diabetes who had high variation of fasting blood glucose. The insulin antibody level was measured, and correlations of glycemic variability with antibody levels, binding rates, and other clinical factors were investigated. The standard deviation (SD) of the 30-day morning selfmonitored fasting blood glucose concentration (FBG SD) was evaluated as an index of glycemic variability. The mean glucose level was $159.8 \pm 42.1 \mathrm{mg} / \mathrm{dL}$ and the FBG SD was $47.5 \pm 22.0 \mathrm{mg} / \mathrm{dL}$. Glycemic variability (FBG SD) was positively correlated with insulin antibody level, but not with insulin antibody binding rate, and had a negative correlation with C-peptide immunoreactivity/plasma glucose (CPR/PG) and positive correlations with diabetes duration, basal insulin dose and bolus insulin dose. Glycemic variability was not correlated with BMI, HbAlc or age. In multiple regression analysis of glycemic variability, CPR/PG was the only significant related factor. The results showed that glycemic variability was mainly influenced by endogenous insulin secretion capacity and was high in patients with high insulin antibody levels. In some patients with a high insulin antibody titer, the antibody may have an effect on the variability of the fasting glucose concentration in type 1 diabetes.
\end{abstract}

Key words: Type1 diabetes, Glycemic variability, Insulin antibody, CPR/PG

THE FASTING blood glucose concentration in type 1 diabetes may vary without being much affected by diet and exercise. Such glycemic variability makes it difficult to achieve good glycemic control. Fasting blood glucose is also important for prediction of morning hypoglycemia, and a number of studies have recently linked hypoglycemia to cardiovascular events and increased dementia [1-3]. Continuous glucose monitoring (CGM) is used to estimate nocturnal hypoglycemia, but this provides only short-term limited information. To obtain more precise information on nocturnal hypoglycemia, we used data for morning fasting blood glucose obtained by self-monitoring of blood glucose (SMBG).

Submitted Nov. 18, 2015; Accepted Mar. 30, 2016 as EJ15-0647 Released online in J-STAGE as advance publication May 11, 2016 Correspondence to: Naotake Hashimoto, Department of Diabetes, Endocrine and Metabolic Diseases, Tokyo Women's Medical University, Yachiyo Medical Center, 477-96, Owadashinden, Yachiyo 276-8524, Japan.

E-mail: hashimoto.naotake@twmu.ac.jp

(c) The Japan Endocrine Society
Case reports have linked insulin antibodies produced by insulin therapy to insulin autoimmune syndrome (IAS) [4] and glycemic variability [5]. However, the association between glycemic variability and insulin antibodies is unclear. A second-generation method for quantitative analysis of insulin antibodies with a highly sensitive radioimmunoassay (RIA) has been available since April 2009. Although the insulin antibody titer and binding rate are useful in diagnosis of type 1 diabetes [6], the association with glycemic variability has not been determined. Therefore, in this study, we investigated the cause of glycemic variability and the relationships of glycemic variability with insulin antibody level and binding rate and other clinical factors in patients with type 1 diabetes with fluctuating blood glucose.

\section{Materials and Methods}

\section{Study design}

The subjects were 54 patients with type 1 diabe- 
tes under treatment at Yachiyo Medical Center, Tokyo Women's Medical University, who were found to have high variation of fasting blood glucose by physicians. Type 1 diabetes was diagnosed by the expert committee on the diagnosis and classification of diabetes mellitus from the American Diabetes Association [7]. The patients were treated with continuous subcutaneous insulin infusion (CSII) or multiple daily insulin injection (MDI), but still had marked glycemic variability. Insulin antibody level and binding rate were measured using a RIA (Yamasa Corp., Chiba, Japan). Murayama et al. have shown that isothiazolinone derivatives such as ProClin300 are effective in reducing non-specific binding of $\left[{ }^{125} \mathrm{I}\right]$ insulin and improve the performance of insulin antibody RIAs using polyethylene glycol separation [6].

The standard deviation (SD) of the 30-day morning fasting blood glucose (FBG SD) was determined by SMBG and used as an index of glycemic variability. Data for the morning after bedtime hypoglycemia and hyperglycemia were excluded since the patients took glucose and a supplementary diet or injected additional insulin. Age, diabetes duration, height, body weight, BMI, insulin dose, HbAlc, C-peptide immunoreactivity/plasma glucose (CPR/PG), retinopathy, and nephropathy were also recorded. Fundoscopic examinations were performed through dilated pupils by ophthalmologists in all patients, and classified as (1) no evidence of diabetic retinopathy; (2) simple diabetic retinopathy (SDR); and (3) pre-proliferative retinopathy or proliferative retinopathy. Retinopathy was defined as the appearance of SDR or more severe grade in one eye. Normo-, micro- and macroalbuminuria were defined as having urinary excretion of albu$\min <30 \mathrm{mg} / \mathrm{g} \cdot$ creatinine, 30 to $299 \mathrm{mg} / \mathrm{g} \cdot$ creatinine and $\geq 300 \mathrm{mg} / \mathrm{g} \cdot$ creatinine. Nephropathy was defined as a urinary excretion of albumin equal to or greater than $30 \mathrm{mg} / \mathrm{g} \cdot$ creatinine from samples at any time in the absence of urinary tract infection.

Patients with onset of less than two years, those with pancreatic cancer or liver cirrhosis, and those for whom SMBG data were judged to be unreliable were excluded.

The patients were divided into three groups using the tertile of insulin antibody concentrations: $\mathrm{H}(>$ $3,000 \mathrm{nU} / \mathrm{mL}, \mathrm{n}=15), \mathrm{M}(800-3,000 \mathrm{nU} / \mathrm{mL}, \mathrm{n}=21)$ and $\mathrm{L}(<800 \mathrm{nU} / \mathrm{mL}, \mathrm{n}=18)$. Glycemic variability, diabetes duration, BMI, insulin dose, $\mathrm{HbAlc}, \mathrm{CPR} / \mathrm{PG}$, and insulin antibody binding rate were compared among these groups. Patients with an insulin antibody level
$>5,000 \mathrm{nU} / \mathrm{mL}$ were taken to have a level of $5,000 \mathrm{nU} /$ $\mathrm{mL}$ because the range of the assay does not extend to high concentrations due to dilution of serum.

\section{Statistical analysis}

All data are shown as mean \pm SD. HbA1c is shown as the National Glycohemoglobin Standardization Program (NGSP) value based on the recommendation of the Japan Diabetes Society [8]. Some patients were in state of CPR negative (expressed as $<0.1 \mathrm{ng} /$ $\mathrm{mL}$ ), so we calculated CPR of those patients as $0.1 \mathrm{ng} /$ $\mathrm{mL}$. Differences between two groups were examined by Sudent's $t$ test and those among three groups by onefactor analysis of variance (ANOVA). Multiple logistic regression analysis was performed to evaluate the relationship between patients with versus patients without retinopathy, nephropathy (categorical variable, yes or no). Associations between variables were determined by Pearson correlation coefficient in simple and multiple regression analyses. Values of $p<0.05$ were considered significant. All analyses were carried out using Stat View ver. 5.0 (SAS Institute Inc., Cary, NC, USA) and Stat Flex ver. 6.0 (Artech Co., Ltd., Osaka, Japan).

\section{Ethical considerations}

The study was approved by the Research Ethics Committee of Tokyo Women's Medical University.

\section{Results}

\section{Characteristics of the patients}

The characteristics of the patients are shown in Table 1. The patients included 16 males and 38 females, their mean age was $50.7 \pm 16.7$ years, diabetes duration was $16.2 \pm 11.5$ years, and BMI was $22.9 \pm 3.0 \mathrm{~kg} /$ $\mathrm{m}^{2}$. Of the 54 patients, 34 had acute onset, 19 had slowly progressive insulin dependent diabetes mellitus (SPIDDM), and 1 was fluminant; 47 used MDI and 7 used CSII; and 32 used insulin aspart, 12 used insulin lispro, 1 used insulin glulisine, 7 used human insulin R, 27 used insulin detemir, 13 used insulin glargine, 4 used neutral protamine Hagedorn, and 3 used insulin aspart 30 mix. Overall, the patients used one or a combination of up to three types of insulin. The basal insulin dose was $0.27 \pm 0.17 \mathrm{U} / \mathrm{kg} /$ day and the bolus insulin dose was $0.44 \pm 0.19 \mathrm{U} / \mathrm{kg} /$ day. HbAlc was $8.36 \pm 1.40$ $\%$, possibly due to glycemic variability. $(\mathrm{CPR} / \mathrm{PG}) \times 100$ was $0.25 \pm 0.24 \mathrm{ng} / \mathrm{mL} / \mathrm{mg}$. The insulin antibody level ranged from $<125 \mathrm{nU} / \mathrm{mL}$ to $>5,000 \mathrm{nU} / \mathrm{mL}$ (the assay 
Table 1 Characteristics of patients

\begin{tabular}{|c|c|}
\hline$\overline{\mathrm{N}}$ (male/female) & $54(16 / 38)$ \\
\hline Age (years) & $50.7 \pm 16.7$ \\
\hline Duration of diabetes (years) & $16.2 \pm 11.5$ \\
\hline Height $(\mathrm{cm})$ & $158.1 \pm 9.0$ \\
\hline Body weight (kg) & $57.3 \pm 9.3$ \\
\hline BMI $\left(\mathrm{kg} / \mathrm{m}^{2}\right)$ & $22.9 \pm 3.0$ \\
\hline Insulin dose basal* (U/day/kg) & $0.27 \pm 0.17$ \\
\hline Insulin dose bolus (U/day/kg) & $0.44 \pm 0.19$ \\
\hline $\mathrm{HbA1c}(\%)$ & $8.36 \pm 1.40$ \\
\hline $\mathrm{CPR} / \mathrm{PG} \times 100(\mathrm{ng} / \mathrm{mL} / \mathrm{mg})$ & $0.25 \pm 0.24$ \\
\hline Retinopathy & $22 / 54(40.1 \%)$ \\
\hline Nephropathy & $14 / 54(25.9 \%)$ \\
\hline \multicolumn{2}{|c|}{ SMBG data and glycemic variability } \\
\hline Mean glucose $(\mathrm{mg} / \mathrm{dL})$ & $159.8 \pm 42.1$ \\
\hline FBG SD $(\mathrm{mg} / \mathrm{dL})$ & $47.5 \pm 22.0$ \\
\hline \multicolumn{2}{|c|}{$\begin{array}{l}\text { Data are shown as mean } \pm \mathrm{SD} \text { or } \mathrm{N}(\%) \text {. CPR/PG, C-peptide } \\
\text { immunoreactivity/plasma glucose; SMBG, self-monitoring of } \\
\text { blood glucose; FBG SD, SD of fasting blood glucose. * } 7 \text { patients } \\
\text { used continuous subcutaneous insulin infusion (CSII). } 47 \text { patients } \\
\text { used multiple daily insulin infusion (MDI). Among them, } 27 \\
\text { used insulin detemir, } 13 \text { used insulin glargine, and } 7 \text { used neutral } \\
\text { protamine Hagedorrn as basal insulin. }\end{array}$} \\
\hline
\end{tabular}

range was 125 to $5,000 \mathrm{nU} / \mathrm{mL}$ ), and the insulin antibody binding rate was $0.4 \%$ to $60.4 \%$. The mean morning fasting blood glucose concentration in SMBG was $159.8 \pm 42.1 \mathrm{mg} / \mathrm{dL}$, with a SD of $47.5 \pm 22.0 \mathrm{mg} / \mathrm{dL}$.

\section{Fasting blood glucose variability and microvascular complications}

Glycemic variability (FBG SD) was significantly higher in patients with retinopathy $(\mathrm{n}=32)$ than in those without retinopathy $(\mathrm{n}=22)(41.5 \pm 22.4 v s .56 .4 \pm 18.4$ $\mathrm{mg} / \mathrm{dL}, p=0.0127$ ), and in patients with nephropathy $(\mathrm{n}=14)$ compared to those without nephropathy $(\mathrm{n}=40)(43.9 \pm 21.8$ vs. $58.1 \pm 19.8 \mathrm{mg} / \mathrm{dL}, p=0.0362)$ by Student's $t$ test. However, neither retinopathy nor nephropathy had an association with glycemic variability after adjusted some clinical parameters including duration of diabetes (data is not shown).

\section{Fasting blood glucose variability and clinical factors}

Glycemic variability (FBG SD) had a significant negative correlation with $\mathrm{CPR} / \mathrm{PG}(\mathrm{R}=-0.454$, $p=0.0005)$ and significant positive correlations with diabetes duration ( $\mathrm{R}=0.328, p=0.0149)$, basal insulin dose $(\mathrm{R}=0.305, p=0.0243)$, and bolus insulin dose $(\mathrm{R}=0.383, p=0.0040)$ (Fig. 1$)$, but was not significantly correlated with BMI or HbA1c (Table 2). In multiple regression analysis of glycemic variability, CPR/ PG was the only significantly related factor (Table 3 ).

\section{Fasting blood glucose variability and insulin antibody}

Glycemic variability (FBG SD) was significantly positively correlated with insulin antibody levels $(\mathrm{R}=0.309, p=0.0226)$ (Table 2, Fig. 2). The glycemic variability was $57.6 \pm 25.3,47.5 \pm 23.0$, and $39.2 \pm 14.2$ $\mathrm{mg} / \mathrm{dL}$ in groups $\mathrm{H}(\mathrm{n}=15), \mathrm{M}(\mathrm{n}=21)$, and $\mathrm{L}(\mathrm{n}=18)$, respectively, and was significantly higher in group $\mathrm{H}$ than in group L ( $p=0.0168)$ (Table 4$)$. Glycemic variability was not correlated with the insulin antibody binding rate (Fig. 2), but the insulin antibody level was significantly correlated with the binding rate $(\mathrm{R}=0.830$, $p<0.0001$ ) (Fig. 2). The insulin antibody binding rates were $27.8 \pm 17.5 \%, 5.7 \pm 1.8 \%$, and $1.4 \pm 1.9 \%$ in groups $\mathrm{H}, \mathrm{M}$, and L, respectively. Diabetes duration in group $\mathrm{H}$ was significantly longer than that in group $\mathrm{L}$ ( $p=0.0368$ ), and $\mathrm{CPR} / \mathrm{PG}$ in group $\mathrm{M}$ was significantly less than that in group L ( $p=0.0456)$ (Table 4). Of note, the proportion of acute-onset type 1 diabetes was $60 \%$ in group $\mathrm{H}, 61.9 \%$ in group $\mathrm{M}$, and $66.7 \%$ in group L.

\section{Discussion}

In this study, we found that (1) glycemic variation was significantly correlated with insulin antibody levels, but not with insulin antibody binding rates; (2) in patients with high insulin antibody levels, the insulin antibody binding rate and glycemic variation were high; (3) neither retinopathy nor nephropathy had an association with glycemic variation; (4) glycemic variation was negatively correlated with CPR/PG and positively correlated with diabetes duration, basal insulin dose and bolus insulin dose, but not correlated with BMI, HbAlc and age; and (5) in multiple regression analysis, CPR/PG was the only significant factor associated with glycemic variation.

Glycemic variability in type 1 diabetes may be due to non-compliance with insulin injection, an erroneous injection technique, the skin condition at the insulin injection site, and irregularity of the basal insulin injection time. An inappropriate prescribed insulin dose, physiological variation of insulin absorption, autonomic neuropathy, and the presence of insulin antibody may also be related to glycemic variability. Our results showed that glycemic variability was negatively correlated with CPR/PG and positively correlated with diabetes duration, basal insulin dose and bolus insulin dose. With a longer diabetes duration, reduced endogenous insulin secretion may be associated with 
(a)

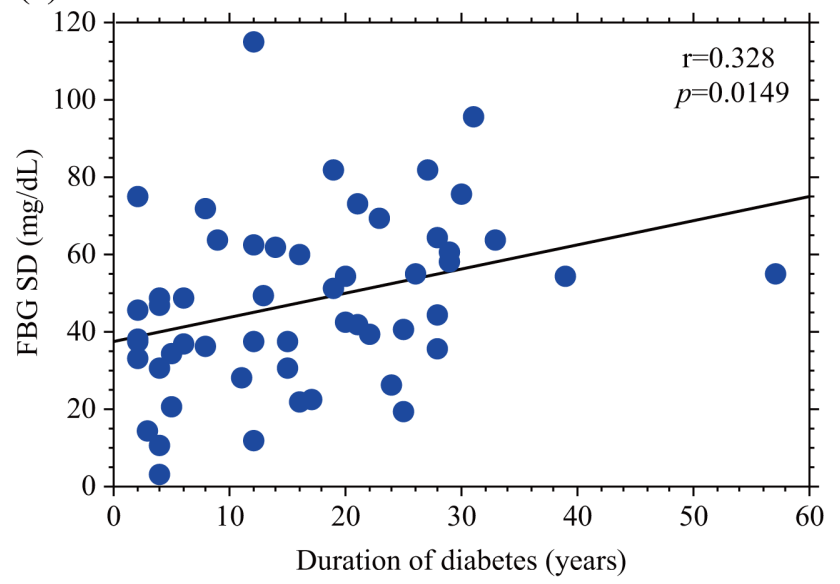

(c)

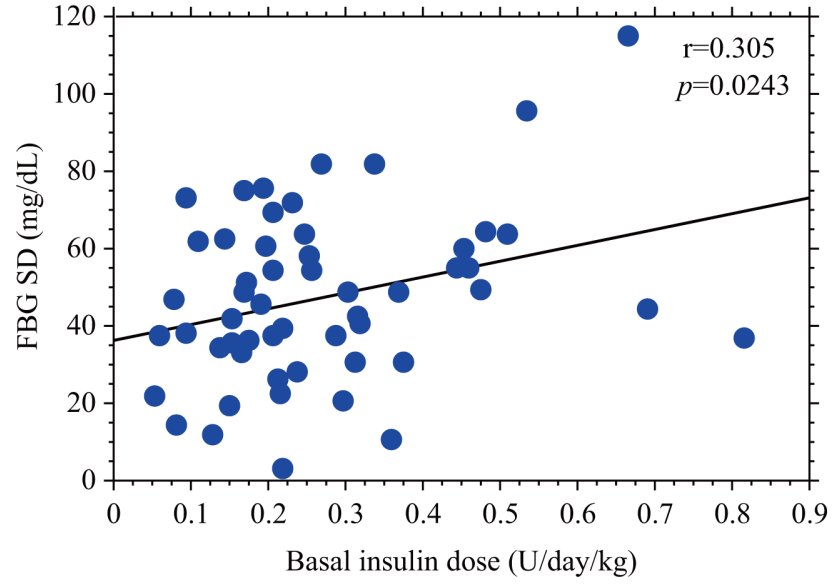

(b)

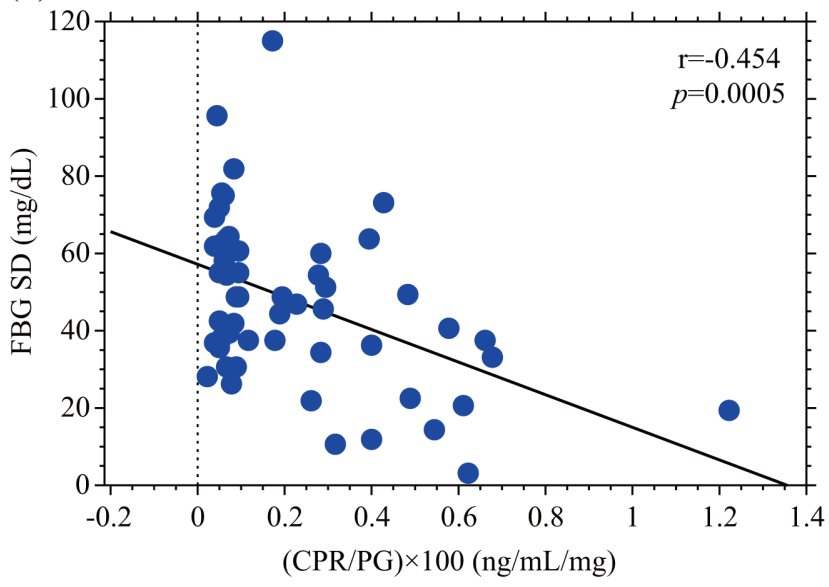

(d)

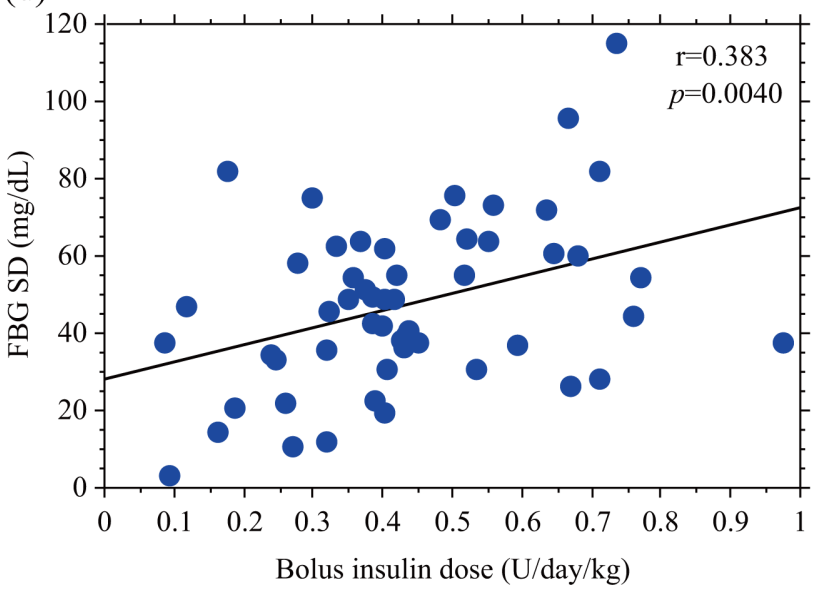

Fig. 1 Correlations of glycemic variability (FBG SD) with (a) duration of diabetes, (b) CPR/PG $\times 100$, (c) basal insulin dose, and (d) bolus insulin dose. Glycemic variability (FBG SD) had a significant negative correlation with $\mathrm{CPR} / \mathrm{PG}(\mathrm{R}=-0.454, p=0.0005)$ and significant positive correlations with diabetes duration $(\mathrm{R}=0.328, p=0.0149)$, basal insulin dose $(\mathrm{R}=0.305, p=0.0243)$, and bolus insulin dose $(\mathrm{R}=0.383, p=0.0040)$.

Table 2 Univariate correlations between glycemic variability (FBG SD) and clinical factors

\begin{tabular}{lcc}
\hline & $\mathrm{r}$ & $P$ value \\
\hline Age (years) & -0.240 & 0.0798 \\
Duration of diabetes (years) & 0.328 & 0.0149 \\
BMI $\left(\mathrm{kg} / \mathrm{m}^{2}\right)$ & 0.129 & 0.3534 \\
Basal insulin dose (U/day $/ \mathrm{kg})$ & 0.305 & 0.0243 \\
Bolus insulin dose $(\mathrm{U} / \mathrm{day} / \mathrm{kg})$ & 0.383 & 0.0040 \\
$\mathrm{HbA1c}(\%)$ & 0.125 & 0.3679 \\
$\mathrm{CPR} / \mathrm{PG} \times 100(\mathrm{ng} / \mathrm{mL} / \mathrm{mg})$ & -0.454 & 0.0005 \\
Insulin antibody level $(\mathrm{nU} / \mathrm{mL})$ & 0.309 & 0.0226 \\
Insulin antibody binding rate $(\%)$ & 0.159 & 0.2524 \\
\hline
\end{tabular}

Table 3 Multiple regression analysis of glycemic variability (FBG SD)

\begin{tabular}{lcc}
\hline Variables & $\beta \pm \mathrm{SE}(\beta)$ & $P$ value \\
\hline Sex & $4.74 \pm 6.48$ & 0.468 \\
Age (years) & $-0.31 \pm 0.17$ & 0.085 \\
Duration of diabetes (years) & $0.23 \pm 0.30$ & 0.453 \\
BMI $\left(\mathrm{kg} / \mathrm{m}^{2}\right)$ & $0.28 \pm 0.99$ & 0.781 \\
$\mathrm{HbA1c}(\%)$ & $0.43 \pm 1.97$ & 0.828 \\
CPR/PG $\times 100(\mathrm{ng} / \mathrm{mL} / \mathrm{mg})$ & $-29.86 \pm 12.39$ & 0.020 \\
Insulin antibody level $(\mathrm{nU} / \mathrm{mL})$ & $0.0047 \pm 0.0033$ & 0.162 \\
Insulin antibody binding rate $(\%)$ & $-0.32 \pm 0.39$ & 0.409 \\
Retinopathy & $12.34 \pm 6.89$ & 0.080 \\
Nephropathy & $-0.90 \pm 6.83$ & 0.896 \\
\hline
\end{tabular}


(a)

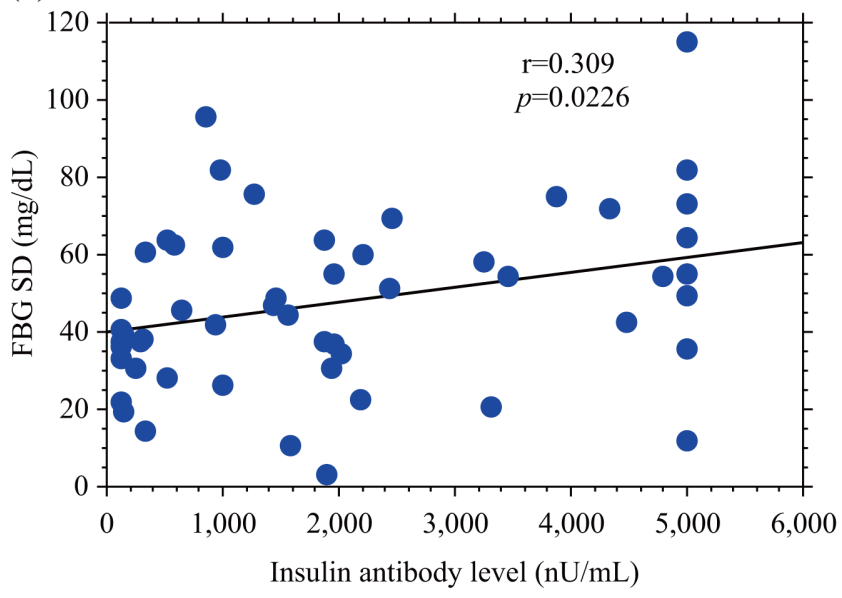

(b)

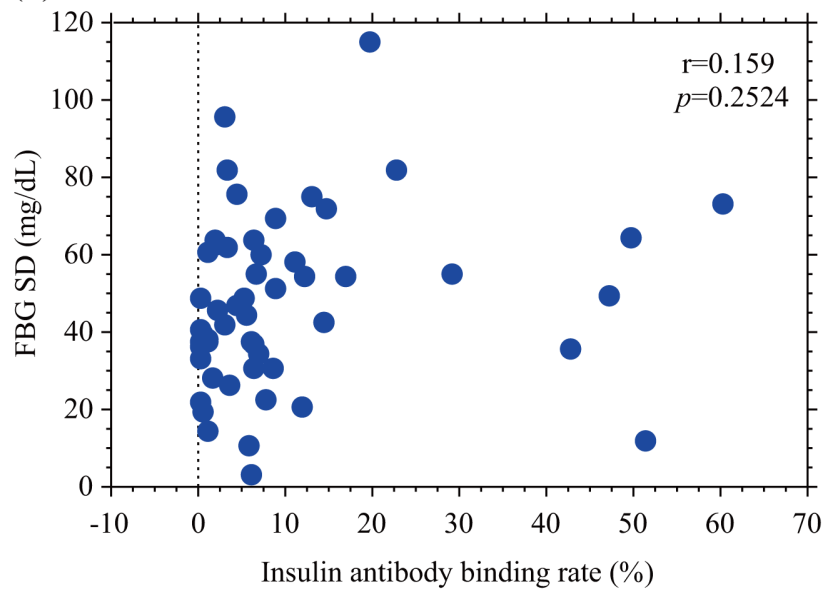

(c)

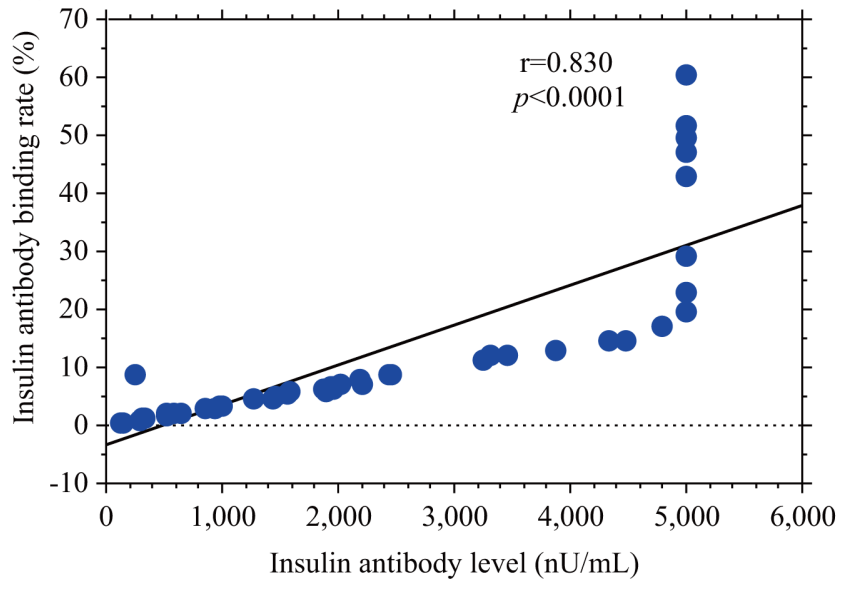

Fig. 2 Correlations of (a) glycemic variability (FBG SD) with insulin antibody concentration, (b) glycemic variability (FBG SD) with insulin antibody binding rate, and (c) insulin antibody level and binding rate. Glycemic variability (FBG SD) was significantly positively correlated with insulin antibody concentration $(\mathrm{R}=0.309, p=0.0226)$, but not with insulin antibody binding rate. Insulin antibody level was significantly correlated with insulin antibody binding rate $(\mathrm{R}=0.830, p<0.0001)$.

Table 4 Relationship of insulin antibody levels ( $\mathrm{H}>3,000, \mathrm{M} 800-3,000, \mathrm{~L}<800 \mathrm{IU} / \mathrm{mL})$ with clinical parameters

\begin{tabular}{lccc}
\hline & $\mathrm{H}(\mathrm{n}=15)$ & $\mathrm{M}(\mathrm{n}=21)$ & $\mathrm{L}(\mathrm{n}=18)$ \\
\hline FBG SD $(\mathrm{mg} / \mathrm{dL})$ & $57.6 \pm 25.3 *$ & $47.5 \pm 23.0$ & $39.2 \pm 14.2$ \\
Duration of diabetes (years) & $21.4 \pm 14.2 *$ & $15.2 \pm 9.5$ & $13.0 \pm 10.2$ \\
BMI $\left(\mathrm{kg} / \mathrm{m}^{2}\right)$ & $24.1 \pm 3.7$ & $22.5 \pm 2.1$ & $22.4 \pm 3.2$ \\
Basal insulin dose (U/day/kg) & $0.300 \pm 0.158$ & $0.315 \pm 0.196 * *$ & $0.196 \pm 0.097$ \\
Bolus insulin dose (U/day/kg) & $0.466 \pm 0.185$ & $0.438 \pm 0.185$ & $0.412 \pm 0.203$ \\
HbA1c $(\%)$ & $8.56 \pm 1.18$ & $8.03 \pm 1.05$ & $8.59 \pm 1.84$ \\
CPR/PG $\times 100(\mathrm{ng} / \mathrm{mL} / \mathrm{mg})$ & $0.195 \pm 0.193$ & $0.173 \pm 0.160 * *$ & $0.325 \pm 0.315$ \\
Insulin antibody binding rate $(\%)$ & $27.8 \pm 17.5 * * *$ & $5.7 \pm 1.8$ & $1.4 \pm 1.9$ \\
\hline
\end{tabular}

Date are shown as mean $\pm \mathrm{SD}, * p<0.05 \mathrm{H} v s . \mathrm{L},{ }^{* *} p<0.05 \mathrm{M} v s . \mathrm{L}, * * * p<0.01 \mathrm{H} v s . \mathrm{M}, \mathrm{H} v s . \mathrm{L}$ by ANOVA. 
progression of autonomic neuropathy, and autonomic disturbance is thought to be associated with glycemic variability [9]. Reduced endogenous insulin secretion also requires a higher basal insulin dose, and this may be linked to greater glycemic variability because it is likely to be difficult to increase basal insulin despite the low fasting blood glucose concentration.

Age, diabetes duration, GA/HbAlc, and betacell function have all been associated with glycemic variability in Japanese patients with diabetes [10]. However, the subjects included patients with type 1 and type 2 diabetes, glycemic variability was assessed by SD and MAGE (mean amplitude of glycemic excursions) calculated from CGM, and beta-cell function was assessed using the postprandial CPR index [10]. Furthermore, in a subpopulation of patients with type 1 diabetes $(n=20)$, clinical parameters had no significant correlation with glycemic variability, and multivariate analysis of the patients with type 1 diabetes was not possible due to the small sample size [10]. Of particular importance, we found that CPR/PG was the only significant factor associated with glycemic variability in multivariate analysis.

Our results suggest that development of neither retinopathy nor nephropathy is associated with glycemic variability after adjusted some clinical parameters. In the Epidemiology of Diabetes Interventions and Complications (EDIC) study, in which longer-term follow-up of the Diabetes Control and Complications Trial (DCCT) was performed, glucose variability assessed by SD and MAGE did not predict development of retinopathy or nephropathy [11]. However, patients with fulminant type 1 diabetes may be at high risk for diabetic microangiopathy associated with the lack of endogenous insulin secretion from the onset of diabetes, with the cumulative incidence of each form of microangiopathy found to be significantly higher in fulminant type 1 diabetes than in type 1A diabetes [12].

There is currently no universally accepted standard method for assessment of glycemic variability. We used the SD of the 30-day morning fasting blood glucose concentration in SMBG. There are two reasons for choosing morning fasting blood glucose. First, this excludes the influence of daytime activity and meals. Second, morning fasting blood glucose is important for predicting morning hypoglycemia, and hypoglycemia may increase the risk of arrhythmias [13]. These findings may also be relevant to the "dead-in-bed" syndrome in type 1 diabetes, which occurs at night, typi- cally in patients with asymptomatic hypoglycemia, and an arrhythmic mode of death has been suggested [14]. As same as our study, the report by Takao T et al. [15] used SD of fasting plasma glucose as an index of glucose variability in order to assess the risk of retinopathy. On the other hand, several reports have assessed SD and MAGE from CGM to evaluate glycemic diurnal variability more accurately $[10,16,17]$. However, we wanted to investigate unexpected glycemic variability associated with insulin antibodies, and thus we analyzed inter-day, rather than intra-day, variability. It has been proposed that the average daily risk range (ADRR) or modified lability index (LI) may be better measures of glycemic variability and severity of hypoglycemia than the LI and MAGE, based on a study in Korean patients with type 1 diabetes [18]. However, SD is a convenient index of glycemic variability in patients in whom intensive insulin therapy does not give adequate control [17]. The best method for evaluation of glycemic variability remains to be determined.

The study has several limitations. It was a retrospective cohort study, and information on work habits, intake of alcohol, hour of rising, bedtime, abrupt changes of $\mathrm{HbAlc}$, and frequency of hypoglycemia were not available. It is desirable to examine patients under hospitalization in the same conditions to check the insulin injection site, correct a poor injection technique, maintain diet therapy, and inject basal insulin at a fixed time. Moreover, it is not possible to distinguish between insulin autoantibodies and insulin antibodies caused by insulin therapy in measurement of insulin antibodies in type 1 diabetes. Therefore, we included both kinds of insulin antibodies and we could not analyze the relative proportions. Finally, the study had a small sample size of patients with apparent fasting blood glucose variability noted by physicians. Thus, further prospective studies with a larger sample size are needed to evaluate glycemic variability in type 1 diabetes.

Within these limitations, we conclude that endogenous insulin secretion capacity is mainly responsible for variability of the fasting glucose concentration, and this may be influenced by insulin antibodies in patients with type 1 diabetes with a high insulin antibody titer.

\section{Disclosure}

None of the authors have any potential conflicts of interest associated with this research. 


\section{References}

1. Crane PK, Walker R, Hubbard RA, Li G, Nathan DM, et al. (2013) Glucose levels and risk of dementia. N Engl J Med 369: 540-548.

2. Araki A, Iimuro S, Sakurai T, Umegaki H, Iijima K, et al. (2012) Non-high-density lipoprotein cholesterol: An important predictor of stroke and diabetes-related mortality in Japanese elderly diabetic patients. Geriatr Gerontol Int 12 Supple 1: 18-28.

3. Goto A, Arah OA, Goto M, Terauchi Y, Noda M (2013) Severe hypoglycaemia and cardiovascular disease: systemic review and meta-analysis with bias analysis. $B M J$ 347: f4533.

4. Hirata Y, Uchigata Y (1994) Insulin autoimmune syndrome in Japan. Diabetes Res Clin Pract 24 Suppl: 153-157.

5. Ishizuka T, Ogawa S, Mori T, Nako K, Nakamichi T, et al. (2009) Characteristics of the antibodies of two patients who developed daytime hyperglycemia and morning hypoglycemia because of insulin antibodies. Diabetes Res Clin Pract 84: e21-23.

6. Murayama H, Matsuura N, Kawamura T, Maruyama T, Kikuchi N, et al. (2006) A sensitive radioimmunoassay of insulin autoantibody: reduction of non-specific binding of $\left[{ }^{125} \mathrm{I}\right]$ insulin. J Autoimmun 26: 127-132.

7. The expert committee on the diagnosis and classification of diabetes mellitus (2003) Report of the expert committee on the diagnosis and classification of diabetres mellitus. Diabetes Care 26 Suppl 1: S5-S20.

8. Kashiwagi A, Kasuga M, Araki E, Oka Y, Hanafusa $\mathrm{T}$, et al. (2012) International clinical harmonization of glycated hemoglobin in Japan: From Japan Diabetes Society to National Glycohemoglobin Standardization Program values. Diabetol Int 3: 8-10.

9. Tesfaye S, Boulton AJ, Dyck PJ, Freeman R, Horowitz M, et al. (2010) Diabetic Neuropathies: update on definitions, diagnostic criteria, estimation of severity, and treatments. Diabetes Care 33: 2285-2293.
10. Tanaka C, Saisho Y, Tanaka K, Kou K, Tanaka M, et al. (2014) Factors associated with glycemic variability in Japanese patients with diabetes. Diabetology Int 5: 36-42.

11. Kilpatrick ES, Rigby AS, Atkin SL (2009) Effect of glucose variability on the long-term risk of microvascular complications in type 1 diabetes. Diabetes Care 32: 1901-1903.

12. Murase $Y$, Imagawa A, Hanafusa $T$, Iwahashi $H$, Uchigata Y, et al. (2007) Fulminant type 1 diabetes as a high risk group for diabetic microangiopathy: a nationwide 5-year-study in Japan. Diabetologia 50: 531-537.

13. Chow E, Bernjak A, Williams S, Fawdry RA, Hibbert S, et al. (2014) Risk of cardiac arrhythmias during hypoglycemia in patients with type 2 diabetes and cardiovascular risk. Diabetes 63: 1738-1747.

14. Heller SR (2002) Abnormalities of the electrocardiogram during hypoglycemia: the cause of the dead in bed syndrome? Int J Clin Pract Suppl 129: 27-32.

15. Takao T, Ide T, Yanagisawa H, Kikuchi M, Kawazu S, et al. (2010) The effect of fasting plasma glucose variability on the risk of retinopathy in type 2 diabetic patients: retrospective long-term follow up. Diabetes Res Clin Pract 89: 296-302.

16. Ogawa A, Hayashi A, Kishihara E, Yoshino S, Takeuchi A, et al. (2012) New Indices for Predicting Glycemic Variability. PLoS One 7: e46517.

17. Greven WL, Beulens JWJ, Biesma DH, Faiz S, de Valk HW (2010) Glycemic variability in inadequately controlled type 1 diabetes and type 2 diabetes on intensive insulin therapy: a cross-sectional, observational study. Diabetes Technol Ther 12: 695-699.

18. Kim SK, Kwon SB, Yoon KH, Ahn KJ, Kang JG, et al. (2011) Assessment of glycemic lability and severity of hypoglycemia in Korean patients with type 1 diabetes. Endocr J 58: 433-440. 